\title{
Las aportaciones culturales de 1@s Chican@s a los espacios que habitan en Estados Unidos de Norteamérica
}

\author{
Dra. María Ileana García Gossio ${ }^{1}$
}

A raíz del surgimiento de la Modernidad las manifestaciones culturales de las diversas etnias agrupadas en cada Estado se intentarán asimilarl al modelo de cultura dominante, dando por resultado la creación, en el imaginario social, de un solo EstadoNación. De esta manera la cultura dominante o hegemónica definirá lo que debe ser, lo mexicano o lo francés o lo alemán, por ejemplo, pero el imaginario no corresponderá con los hechos reales y en muchas ocasiones dará lugar a reacciones violentas por parte de los grupos oprimidos. En Estados Unidos, lo WASP (White Anglo Sax and Protestant), se asociará con los ideales de lo que debe ser la nación estadounidense pero en la realidad no solo existirán las manifestaciones de la nación WASP, también estarán las naciones nativas (indígenas), las de origen mexicano, africanas, orientales, etcétera. Ante la presencia multicultural en ese país y al no existir un interculturalismo como política pública, estos grupos, en repetidas ocasiones, han reaccionado violentamente ante los intentos de oposición-asimilación de sus comportamientos culturales. Una forma específica de reacción contracultural ha sido la de los llamados chican@s a diferencia de los hispanics, más adelanta volveremos sobre ello.

Para saber quién soy necesito recurrir a mis raíces y reafirmarme frente a "lo otro" es decir frente a la otredad (consultar Wulf,1999). Saber quién soy permite encontrar y afirmar la identidad, que se permanece en constante movimiento. En la medida que una persona tiene clara su identidad es más factible que sepa demandar los derechos a los que puede acceder como ciudadan@. Las personas de origen mexicano que viven en los Estados Unidos de Norteamérica, para efectos de su identidad, necesitan regresar a sus raíces y estas no las encontrarán en los elementos contenidos en la cultura WASP. ¿Pero, por qué no es posible que el mexico-americano se pueda reconocer en la cultura dominante WASP? Mientras las raíces de lo mexicano son producto de un mestizaje tanto físico como

\footnotetext{
${ }^{1}$ Profesora de tiempo completo del ITESM-CEM, Depto. de Estudios Sociales y Relaciones Internacionales. E-mail: igossio@itesm.mx .
} 
cultural entre lo indígena (principalmente mesoamericano) y lo occidental (a través de lo católico): en términos generales, la cultura hegemónica en Estados Unidos se formó con base en el rechazo a lo indígena (aridoamérica) y la exclusión en el proceso de pureza con sus raíces occidentales (protestantes). Como podemos apreciar la afirmación de identidad jugará un papel decisivo en la conformación de un(a) chican@, apuntemos algunos señalamientos con respecto a la identidad antes de proseguir.

Los seres humanos vamos constituyendo nuestra identidad a través de afirmarnos frente a la otredad es decir, todo lo que no soy yo ${ }^{2}$. La conformación del proceso de identidad $^{3}$ se establece por medio de la relación con los otros y esta solo es posible al relacionar nuestro mundo interno con el mundo externo a través del lenguaje y de dos opuestos simbólicos, por ejemplo: la identidad sexo-genérica, Mujer- Hombre o Heterosexual-Homosexual; la identidad religiosa, Católico-Judío; la identidad étnica, WASP-Indígena, etcétera; de estos pares uno define al otro en ese proceso simbólico.

El lenguaje juega un papel protagónico en la dotación de identidad, con este diseño chicano (1) deseo subrayar la importancia de él en la cultura. Dicha imagen muestra una propuesta contracultural en donde el lenguaje como factor de identidad, integra lo inglés pero a fin de realzar el español y así lo mexicano, por ejemplo: cyber-cholo, varrio virtual, aztlan nation, tacos el pocho. El lenguaje forma parte de la cultura: los símbolos y significados de esta van a ser asignados según las coordenadas espacio-temporales en que vivimos, léase según el contexto cultural en el que nos desarrollamos: influyendo la geografía, la historia, etcétera. Lenguaje, comunicación y cultura irán de la mano en el proceso de la conformación y reafirmación de la identidad. Al interior de una cultura encontramos una cosmovisión que nos ubica en el mundo, nos genera un sentido de pertenencia a ella y nos dota de identidad (autoidentidad e identidad social ${ }^{4}$ ). Además de los valores, costumbres, tradiciones y religión, plasmados en la música, danza y comida por

\footnotetext{
${ }^{2}$ Lo otro se presentará siempre como lo incognoscible y lo sujeto a ser temido por desconocido (consultar: García, 2006, cap. 3), tal vez por ello lo otro, se constituye como lo que teme todo WASP frente a su actitud de pureza y exclusión que ya viene desde la Colonia (consultar ampliamente a: Paz, 1988).

${ }^{3}$ Consultar Serret, 2004.

${ }^{4}$ La organización cultural de una sociedad nos remite al concepto de civilización. Para Octavio Paz, una civilización “ ... es el estilo, la manera que tiene una sociedad de vivir, convivir y morir. Comprende a las artes eróticas y a las culinarias; a la danza y al entierro, al trabajo y al ocio, a los ritos y a las fiestas, a las actitudes ante las mujeres y los niños, los viejos y los extraños (...) Una civilización no solo es un sistema de valores: es un mundo de formas y de conductas, de reglas y de excepciones. Es la parte visible de una sociedad -instituciones, monumentos, ideas, obras cosas- pero sobre todo es su parte sumergida, invisible: las creencias, los deseos, los miedos, las represiones, los sueños.” Paz, 1988: 141-142.
} 
citar algunos ejemplos, encontramos cómo los seres humanos crean y recrean sus propios espacios como parte de dicha identidad.

Deseamos mostrar en este trabajo cómo 1@s chican@s han retomado de los espacios sociales que los rodean, elementos que les ha permitido hacer habitable el entorno ${ }^{5}$ urbano en donde se desenvuelven mediante ciertos factores que los dota de identidad cultural y por ende de conciencia ciudadana. Las imágenes pertenecen a un barrio obrero de población mayoritariamente de origen mexicano en San Diego, California, Estados Unidos, llamado el Barrio Logan. Las creaciones culturales a su entorno urbano han generado aportaciones a su identidad cultural (ni mexicana ni WASP sino algo distinto: Chicano) en Estados Unidos, retomando elementos mexicanos en términos de la creación de un parque, casas, restaurantes, iglesias, mercados, etc.

\section{La Identidad y lucha Chicana}

Los murales ${ }^{6}$ constituyen el intento de una cultura por apropiarse del espacio público para plasmar gráficamente su historia, aspiraciones y proyectos comunitarios así como también señalar las carencias, opresiones, contradicciones e inconformidades en su percepción de la vida. Este mural (1) señala "La Tierra Mía" como lo que era México en el siglo XIX antes de la guerra con Estados Unidos. ¿Qué pasa con 1@s mexican@s que nacieron en lo que actualmente es Estados Unidos, qué pasó con ell@s cuando después de una guerra y pese a las garantías que los tratados de Guadalupe-Hidalgo prometían se volvieron ciudadan@s de segunda en Estados Unidos? ¿Qué sucedió cuando poseedores de una cultura muy distinta a la WASP se encontrarían en un país que les señalaban a ese como el imaginario de lo que debía ser un estadounidense? La discriminación racial y la marginación no se harían esperar: algun@s se irían gradualmente asimilando al american way of life $e^{7}$ pero otr@s irían generando rasgos de resistencia cultural: ahí encontramos el antecedente de1@s chican@s. Un lema chicano reza: nosotros no cruzamos la frontera, la frontera nos cruzó a nosotros.

\footnotetext{
${ }^{5}$ Que en muchas ocasiones, frente a la cultura WASP, resulta hostil.

${ }^{6}$ No olvidemos que los murales callejeros de 1@s chican@s tienen como antecedente al Muralismo mexicano del tiempo de José Vaconcelos (década de los años veinte del siglo XX): con Diego Rivera, José Clemente Orozco, y tiempo después, David Alfaro Siqueiros.

${ }^{7}$ Tal es el caso de los hispanics.
} 
¿Tod@s 1@s mexicoamerican@s coinciden en la necesidad de encontrar sus orígenes en México y en reivindicarlos? Unos buscarán sus raíces indígenas y occidentales (principalmente españolas), e incluso negras en ocasiones, frente a otros que, se encontraran en un proceso constante de aculturación y asimilación ante lo WASP. Los chican@s buscarán no ser asimilados por la cultura anglosajona - a diferencia de los "Hispanics" - al contrario rescatarán y recrearán, en lo posible, los elementos culturales tanto de origen indígena, negro y occidental que les permitan cobrar un sentido de vida y los dote de una identidad combativa frente a las diferentes imposiciones culturales WASP. Con base en lo anterior, bien podemos señalar que el ser chican@ más que una definición es una actitud de vida combativa que se centra en la lucha por el respeto a los derechos humanos como ciudadan@s estadounidenses. Incluso, yendo más allá de lo anterior, si hablamos de un(a) chican@ como una persona crítica, combativa y consciente de su identidad bien podríamos encontrar a un(a) chican@ no solo en un(a) ciudadan@ estadounidense sino también en cualquier(a) migrante indocumentado ${ }^{8}$, por ejemplo, que cumpla con las características antes señaladas.

En este edificio (3) podemos apreciar un mural ${ }^{9}$ con la imagen central de César Chavez. ¿por qué estas creaciones culturales (murales) no se mantienen en un ámbito privado y ahí permanecen, cuál es la necesidad de mostrar estos elementos en un espacio público, qué aporta a la comunidad que vive y transita por ahí? ¿existirá alguna necesidad de identidad, de reconocerse en ese mural? ¿será una respuesta ante la opresión que viven frente a lo WASP, frente a la cultura dominante? En varios de los murales aparece la imagen de César Chavez ¿quién es este personaje, porqué varias ciudades de la unión americana llevan su nombre? El(la) chican@ se va a identificar por la gente que ha luchado por La Raza pero muy en especial con alguien como César Chávez elemento clave en la década de los 70's del siglo XX y gran líder en la resistencia ante la opresión de 1@s chican@s. César Chavez formó la National Farm Workers Union. En una huelga en los sesenta, 1@s

\footnotetext{
${ }^{8}$ La constante migración indocumentada de México hacia Estados Unidos se constituye como una fuente de nutrientes culturales para las personas de origen mexicano establecidas en ese país que recrean constantemente factores de identidad nacional. De los 30, 000, 000, de latinos en Estados Unidos, encontramos en California al 30\% aproximadamente. Un caso que llama la atención es la ciudad de los Angeles que ocupa el segundo lugar en población de origen mexicana después del Distrito Federal. California por sí sola puede competir con la economía de algún estado de la Unión Europea. Como octava o novena economía del mundo, gran parte de su fortaleza está en la mano de obra barata de 1@s indocumentad@s.

${ }^{9}$ Los murales chicanos plasman temas referentes a: lo indígena, el mestizaje y a los personajes más significativos de la historia de México. Principalmente: Indígenas mesoamericanos, la Virgen de Guadalupe, héroes y heroínas de la Revolución como por ejemplo, Adelitas, Villa, Zapata, los hermanos Flores Magón o liberales como Benito Juárez o Ignacio Zaragoza incluso, personajes del México actual como el Sub-Comandante Marcos.
} 
trabajadores(as) agrícolas dejaron de asistir al campo y las uvas se fueron echando a perder, finalmente el éxito de la huelga se vio plasmado en el aumento de sus salarios y mejores condiciones de trabajo pero principalmente en el reconocimiento de 1@s chican@s como parte importante de la población en los Estados Unidos. César Chávez es un símbolo de combatividad y demanda ante las reivindicaciones sociales ${ }^{10}$.

La existencia de sus Barrios $^{11}$, más cercanos a la comunidad indígena que a la del american dream ${ }^{12}$, comenzaron a ser marginados por parte del Estado norteamericano: los servicios públicos para dotarlos de agua, luz, seguridad, etcétera, se volverían en un principio, limitados e ineficientes. Un ejemplo contrastante lo encontramos en la separación entre los barrios latinos y las residencias californianas ${ }^{13}$ ubicadas respectivamente al este y oeste de los Angeles, California: uno pobre y marginal frente al otro rico y próspero. La respuesta cultural ante tal situación será diversa: la de algunos será la aceptaciónintegración-asimilación a la cultura WASP que los ubicará en la parte baja de la escala social pero otros, reaccionarán exigiendo los derechos que como ciudadan@s les pertenece, creando a la larga movimientos sociales urbanos que los dotarían de identidad como chican@, no como aspirante a WASPy/o hispanic.

\section{La Identidad Chicana de los habitantes del Barrio Logan}

San Diego, California, es una ciudad que se distingue por sus astilleros y por la flota naval de Camp Pendleton, más de la mitad de su población es de origen mexicano, en ella existe una comunidad mexicoamericana llamada el Barrio Logan. Este barrio posee una historia de poco más de 100 años: en un principio fue un barrio de refugiados y desplazados a causa de la Revolución Mexicana, durante la Segunda Guerra Mundial marcó la diferencia al dar paso a la construcción de una consciencia comunitaria cuando jóvenes mexico-americanos fueron reclutados para defender la Costa de San Diego y durante ese tiempo se logró entre ello un fuerte sentimiento de pertenencia al lugar que

\footnotetext{
${ }^{10}$ Tal vez aún más ahora que ya ha muerto.

${ }^{11}$ Mientras el Calpulli mesoamericano tenía sus separaciones y estaba dividido por oficios-ocupaciones: artesanos, tejedores, etc.; los fraccionamientos durante el Porfiriato intentarían anular dicha organización y establecer una más moderna y urbana.

${ }^{12}$ Las bardas no existen en lo WASP a diferencia de México, tal vez por el asunto de individuo y respeto a la propiedad privada (Consultar Pastor, 1989).

${ }^{13}$ Por cierto que las residencias construidas al llamado estilo californiano forman parte de una apropiación de lo colonial mexicano a base de ladrillos, tejas y losetas de barro.
} 
habitaban.

El barrio Logan se encuentra ubicado en el sureste de la ciudad de San Diego y fue nombrado por sus habitantes como "el barrio ombligo del mundo". En términos históricos, representa el segundo barrio chicano de la costa oeste y el de mayor popularidad en las últimas dos décadas. Este espacio urbano ha experimentado diversos cambios físicos: desde la pérdida de conexión con el mar, pasando por una intensa industrialización, hasta el replanteamiento de su espacio como un lugar de resignificación simbólica en donde 1@s chican@s crean y recrean a diario sus comportamientos culturales frente a la penetración WASP.

Al interior de esta comunidad existen personas que se encuentran identificadas más con las raíces del México indígena y mestizo que con el american way of life. Por ahí de fines de la década de los sesenta la comunidad del Barrio solicitó al gobierno de San Diego la creación de un parque (4). Esta propuesta en un principio fue aceptada pero tiempo después, las autoridades estatales comenzaron a evaluar los pros de instalar en ese sitio una estación de policía que apoyara a las carreteras cercanas en lugar de la creación de un parque recreativo. La respuesta de la organización chicana, consistió en una serie de movilización como por ejemplo, instalarse (abril 22 de 1970) durante varios días en ese espacio público para evitar que las grúas y demás maquinaria avanzara en la construcción de las oficinas de policía. A la par de lo anterior varios de sus líderes fueron a gestionar con las autoridades pertinentes, se respetara la decisión original. Uno de los principales líderes y encargados de las negociaciones fue una persona llamada Mike Amador (5), que ahora apreciamos de una manera pública en una calle del Barrio Logan.

Este parque (6) es el resultado de la organización comunitaria del Barrio en donde intervinieron no individu@s aislad@s sino familias enteras que se opusieron comunitariamente a que en ese lugar se instalara una estación de policía. El Chicano Park posee 20 murales y un kiosco y en todos ellos se mantiene una temática social y representación no solo física sino simbólica en torno a la identidad del ser chican@.

Esta imagen (7) nos muestra un ejemplo claro de sincretismo: la pirámide indígena y el altar católico: al fondo en el mural, el ángel que sostiene a la Virgen de Guadalupe y la rosa del milagro. También apreciamos aquí, el mapa de 1803, aproximadamente cuando 
Humboldt pensaba que este Reino de España probablemente constituía una de las regiones más ricas del mundo.

Este anuncio (8) promueve la venta de unos departamentos llamados "mercado", de no pertenecer al apellido ${ }^{14}$, de uno de los conquistadores de la Alta California, el nombre llamaría la atención además de los elementos de identidad cultural a los que alude para hacer atractiva la inversión: la guitarra, maracas, una copa, etcétera, en suma valores de alegría y fiesta (a los que Octavio Paz, 1988 hace referencia), característicos de lo mexicano frente al valor protestante del trabajo. En la siguiente imagen (9), podemos ver a los mercado apartments ya terminados y habitados. La arquitectura mexicana está presente por ejemplo, en los techos de teja, los colores de las construcciones, el arco de la puerta, la herrería, las ventanas e incluso las plantas de ornato.

Este lugar llamado Rancho Fresco (10) vende frutas y verduras como por ejemplo: aguacates, papas y naranjas: lo que bien podría ser el equivalente a un mercado en México. En este lugar de consumo colectivo podemos apreciar en su construcción desde el pórtico para guarecerse del sol hasta los detalles superiores donde se sugiere una pirámide prehispánica por ejemplo, Chichen Itza. En este restaurant (11) Portland, llama la atención la necesidad de apropiación de la calle como un espacio público pese a la existencia de mesas y sillas al interior. Esta construcción forma parte de la arquitectura colonial (remates, copones, macetones y otros mixtilíneos), además nótese los arcos característicos de los mercados mexicanos. En contraesquina, la malla ciclónica que contrasta con los espacios abiertos de los anglosajones.

En esta imagen (12) apreciamos que la fachada antes que comunicarnos en inglés Bakery, subraya el español, Panadería. El inglés es utilizado solo como un medio para resaltar la identidad de las personas de origen mexicano en torno a un elemento cultural, la comida. A través de las vitrinas se exhibe el pan hacia el exterior, hacia la comunidad y no hacia adentro, propio del individuo. Al fondo de esta foto (13) podemos ver una tortilla factory que se llama El Porvenir y al lado izquierdo un estanquillo ${ }^{15}$ como de colonia popular en México que se hace llamar Mike Amador Market. El consumo de refrescos en la población mexicana es tan manifiesto aquí al formar parte del principal atractivo de la

\footnotetext{
${ }^{14}$ Mercado al igual que Coronado y Pinto son apellidos de conquistadores que llegaron a la Alta California. Del latín, Calida (calor) y Fonix (horno).

${ }^{15}$ Que cuenta con refrescos como Boing o Jarritos, chorizo, totopos, cueritos, chicharrones, etcétera.
} 
tienda. El teléfono para llamadas locales nos indica la necesidad de la población que habita ese lugar para usar el teléfono pues probablemente no cuenten suficientemente con ese servicio o se deba a la existencia de indocumentados en esas casas.

En la academia King-Chavez (14) se imparten clases para niñ@s y adult@s además, es un motivo de orgullo y excelencia, como se indica en uno de los mensajes en su página de Internet. Martin Luther King por un lado y César Chávez por el otro como dos estandartes de grupos marginados producto del racismo y la xenofobia: 1@s negr@s y las personas de origen mexicano. Recordemos que el movimiento negro por los derechos civiles (Black Civil Rights Movement) inspiró a muchos líderes y liderezas del movimiento chicano. El Cristianismo protestante en Estados Unidos ha cobrado mucha fuerza al interior de las comunidades de personas de origen mexicano ya que frecuentemente realizan labores de apoyo a su situación económica. Nótese los detalles de la mujer que aún usa mantilla o los establecimientos de comida a la salida de la iglesia (15), tipo mercado sobre ruedas. Finalmente, muestro este mural (16) del Parque Chicano en donde aparecen personajes como El Subcomandante Marcos, Saddam Hussein y otros más, ¿podrían representar símbolos de resistencia al imperialismo estadounidense?

Como pudimos apreciar en esta breve escrito, mientras existan personas dispuestas a reivindicar su identidad como sentido de vida, sus raíces reales o imaginarias, ellas funcionarán como un elemento constante en la afirmación de su Yo frente a la otredad, léase el chicano y la chicana frente al WASP. Si bien las consecuencias en la inexistencia de un sincretismo pueden generar serios problemas de convivencia, el rechazo a ser asimilados por la cultura dominante genera pautas de organización y apropiación en diversos espacios sociales. En el contexto de la nueva economía mundial y la globalización, mientras que por un lado existe una tendencia a uniformar, por otro lado resurgen las identidades locales que buscan reafirmarse dentro de un ámbito regional y/o nacional.

En el caso del Estado de California, de realizarse las proyecciones que se han hecho para el año 2040, los latinos constituirán casi la mitad (48\%) de la población mientras que los anglos representarán menos de un tercio (31\%). Con base en la importancia de estos datos, deseo concluir con una reflexión de Mike Davis (2005), profesor de teoría urbana en California, en donde él señala lo importante que es, que los estudios urbanos en Estados Unidos tomen en cuenta a los latinos como el centro de debate sobre el futuro de la ciudad 
americana, ante su contundente presencia física y cultural que cada vez va mostrando un acentuado crecimiento. 


\section{Referencias Documentales}

- Davis, Mike (2005), "La ciudad al kilo: la conquista latina de los Estados Unidos" en I Latinos alla conquista degli USA, Ed. Feltrinelli, Milán (traducción del italiano de Israel Covarrubias González).

- Díaz de Cossío, Roger y Graciela Orozco (1997), Los mexicanos en Estados Unidos, Sistemas técnicos de edición, México.

- Etxeberria, Xabier (2004) "Nuestra multiculturalidad constitutiva" en: Sociedades Multiculturales, Ediciones Mensajero, Bilbao, España.

- García Gossio, María Ileana (2006), Reconstrucción de identidades sexo-genéricas en la modernidad reflexiva. El acceso de las mujeres al poder público: el caso de Rosario Robles Berlanga, Tesis Doctoral, UIA, México.

- Pastor, Robert y Jorge Castañeda (1989), Límites en la amistad: México y Estados Unidos, Joaquín Mortiz/Planeta, México.

- Paz, Octavio (1988), "México y Estados Unidos: posiciones y contraposiciones”en: Tiempo Nublado, Seix Barral, México.

- Serret, Estela (2004), "Mujeres y hombres en el imaginario social. La impronta del género en las identidades" en García, María Ileana, Mujeres y sociedad en México: nombrar lo innombrable, Porrúa-TEC-Cámara de Diputados, México.

- Wulf, Christopher (1999) “El otro. Perspectivas de la educación intercultural” en: Modernidad y Posmodernidad, Alianza, España.

- http://history.sandiego.edu/gen/projects/178/barriologan-pics.html

- $\quad$ http://www.pocho.com/news/APNmexiporn4499.html 


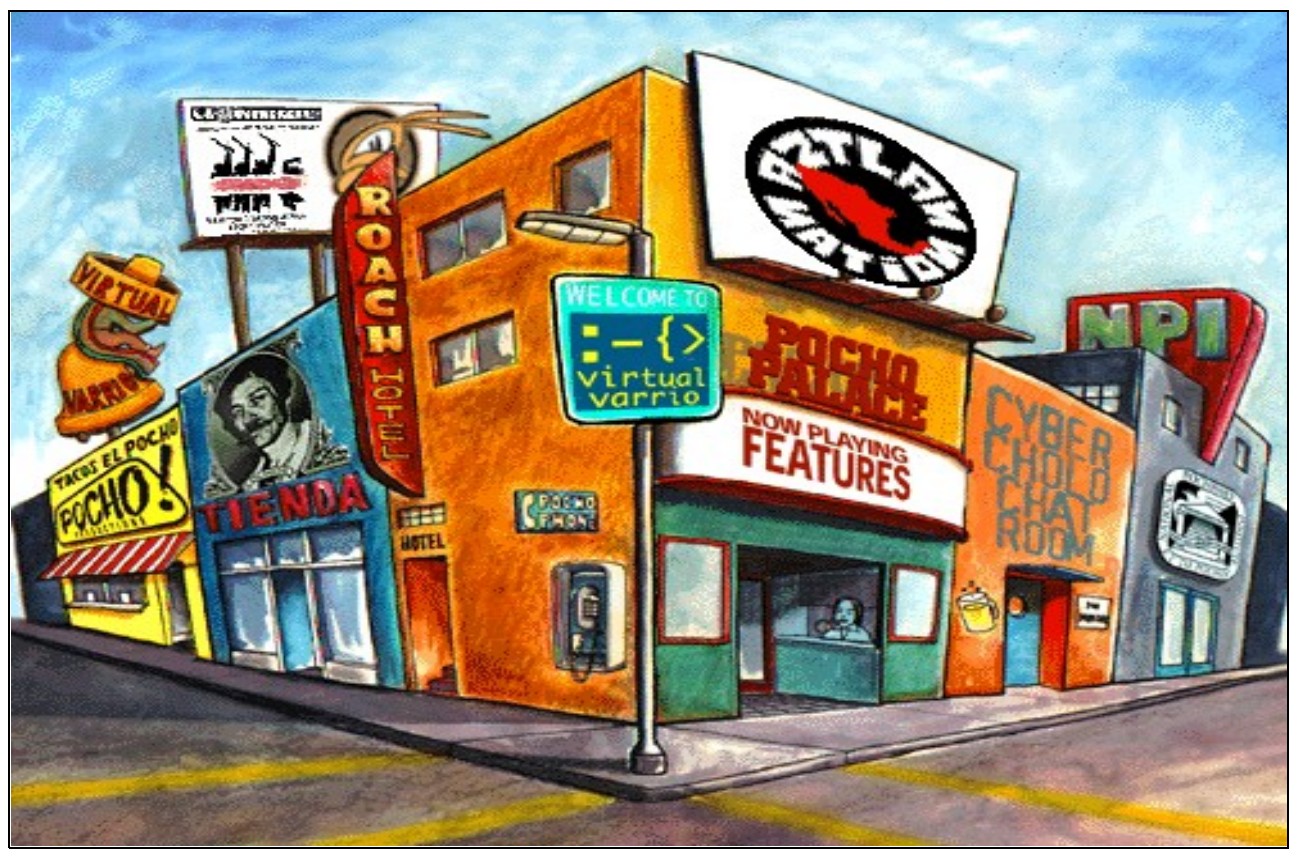

( 1 ) $\quad \underline{\text { http://www.pocho.com/news/APNmexiporn4499.html }}$

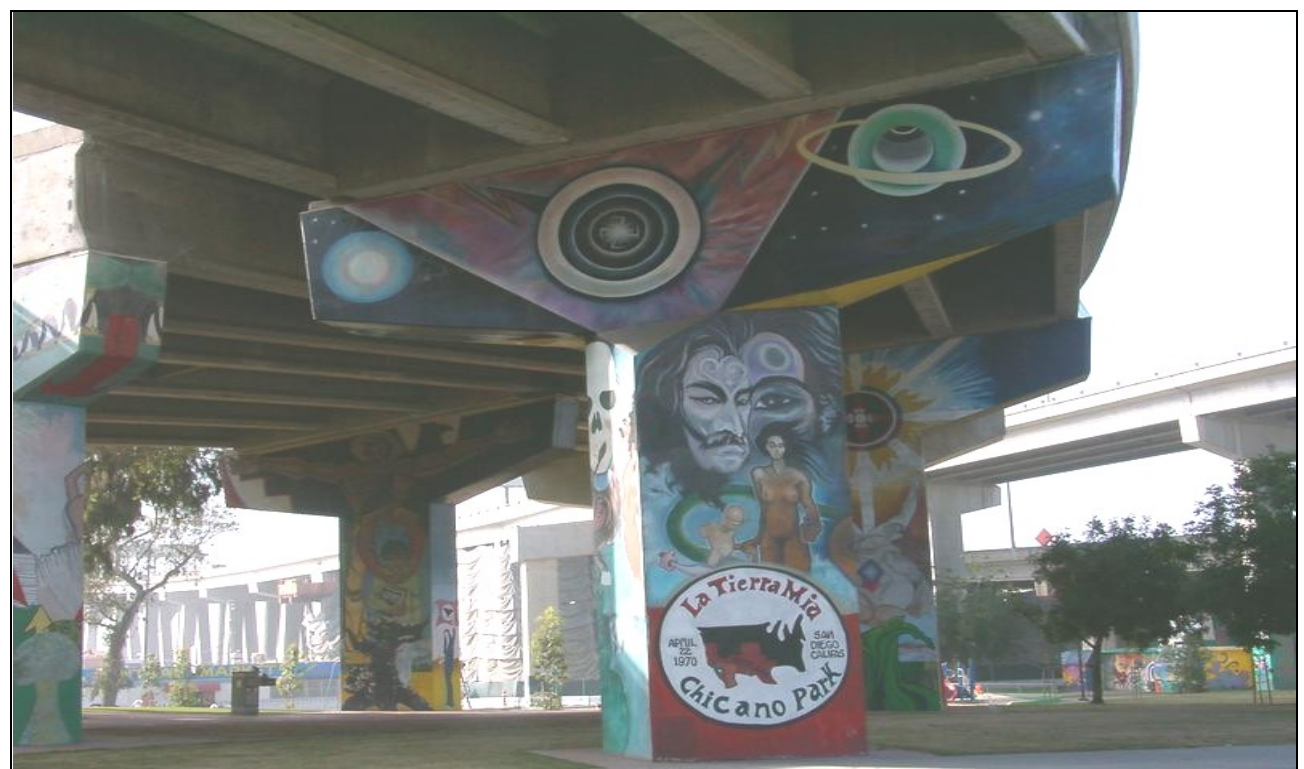

( 2 ) http://history.sandiego.edu/gen/projects/178/barriologan-pics.html 


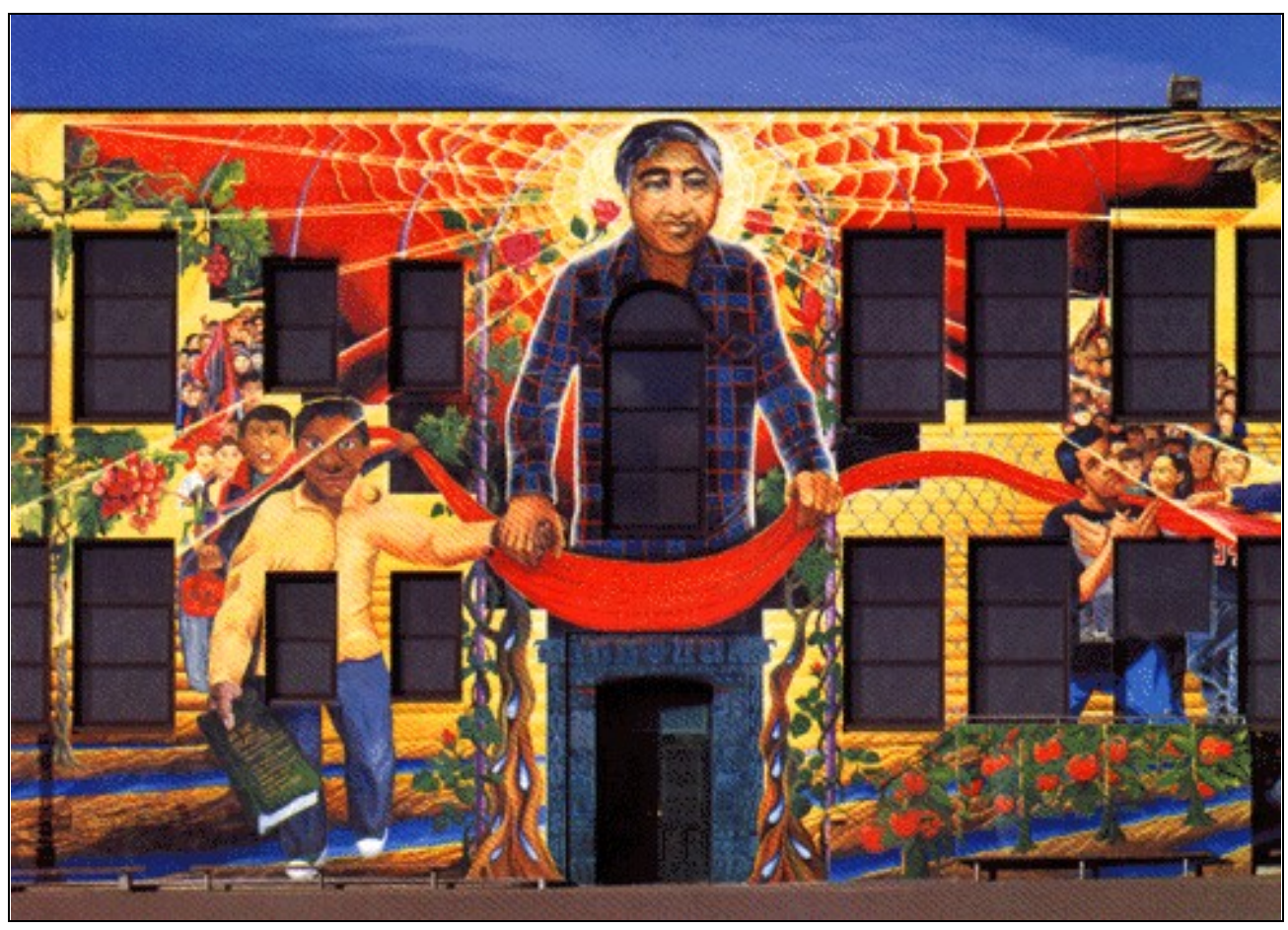

( 3 ) http://www.chavezfoundation.org/ 


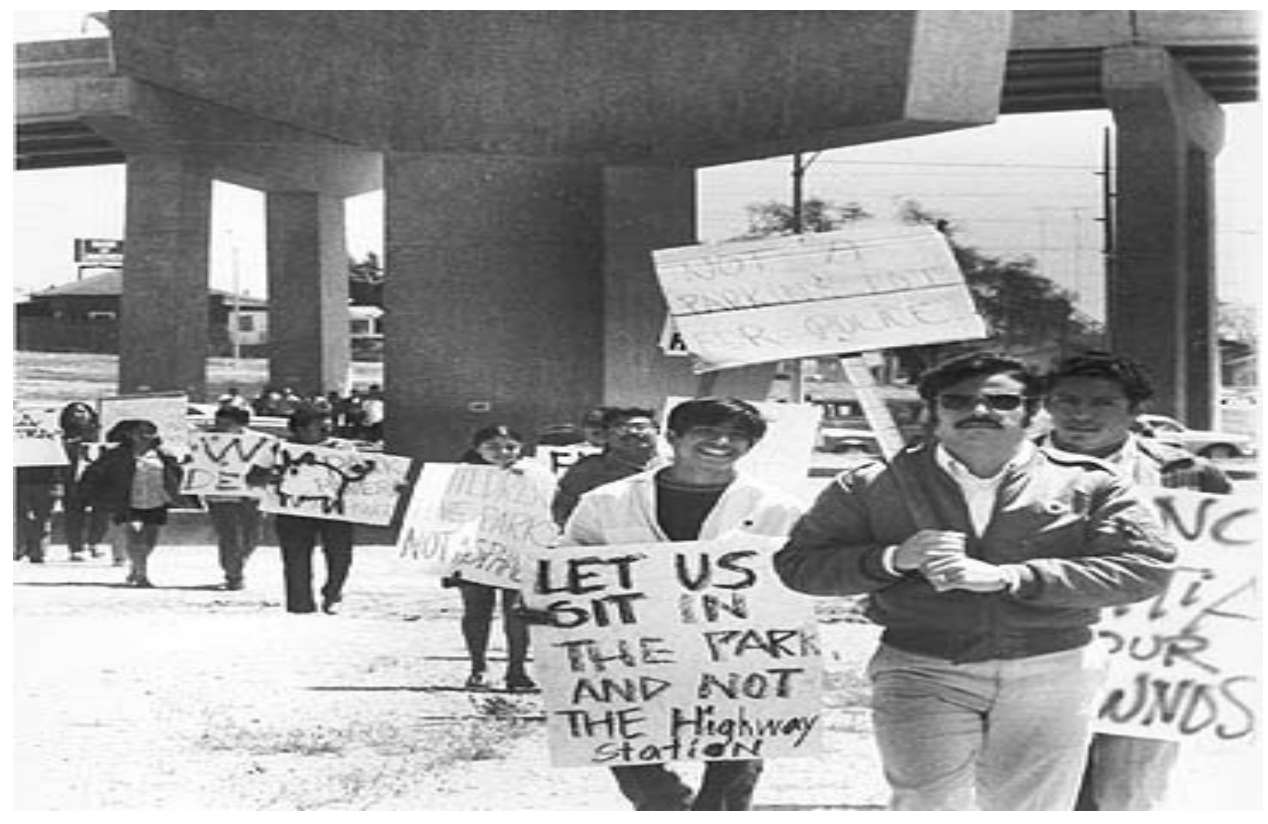

( 4 ) http://69.13.72.231/journal/98winter/chicano.htm

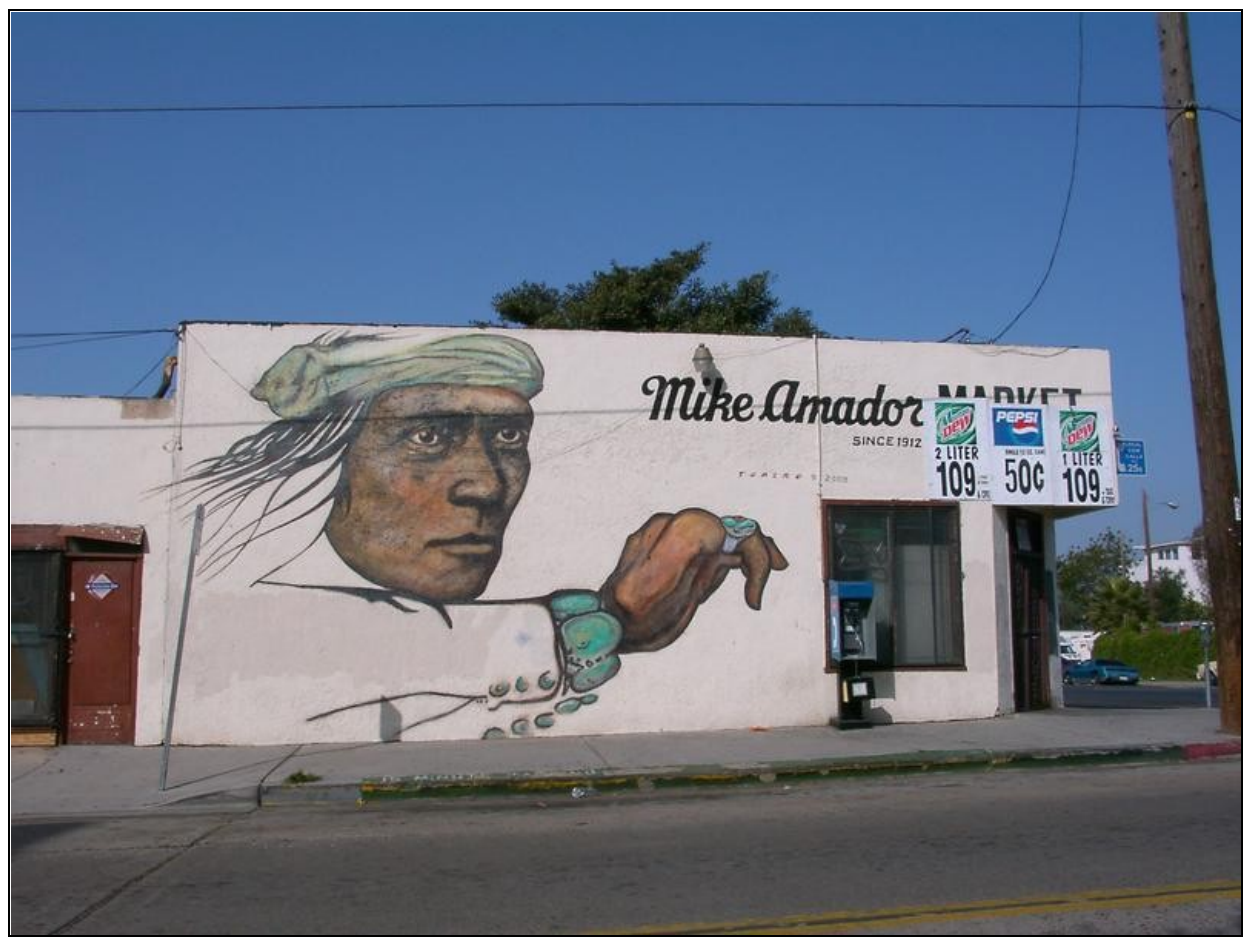

( 5 ) $\quad$ http://history.sandiego.edu/gen/projects/178/barriologan-pics.html 


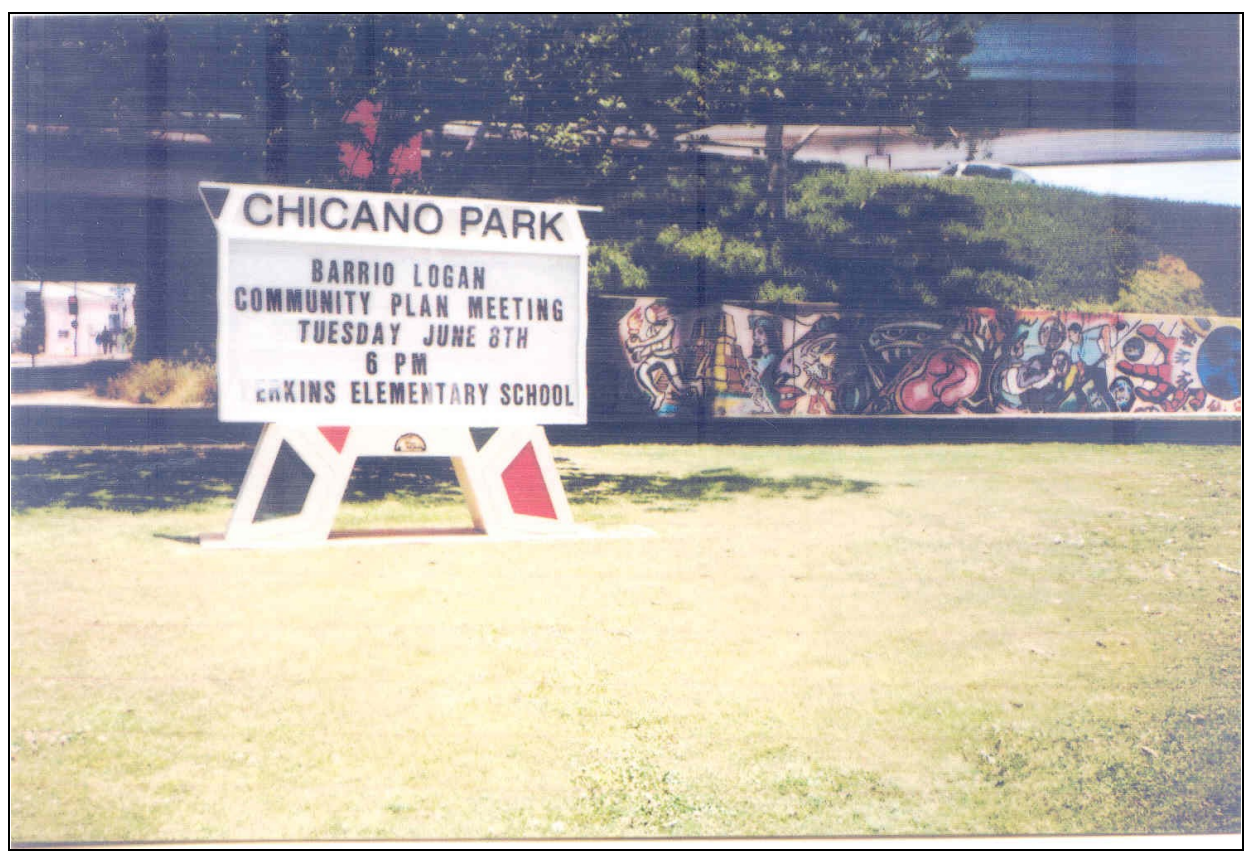

( 6 ) Fotografía de la autora

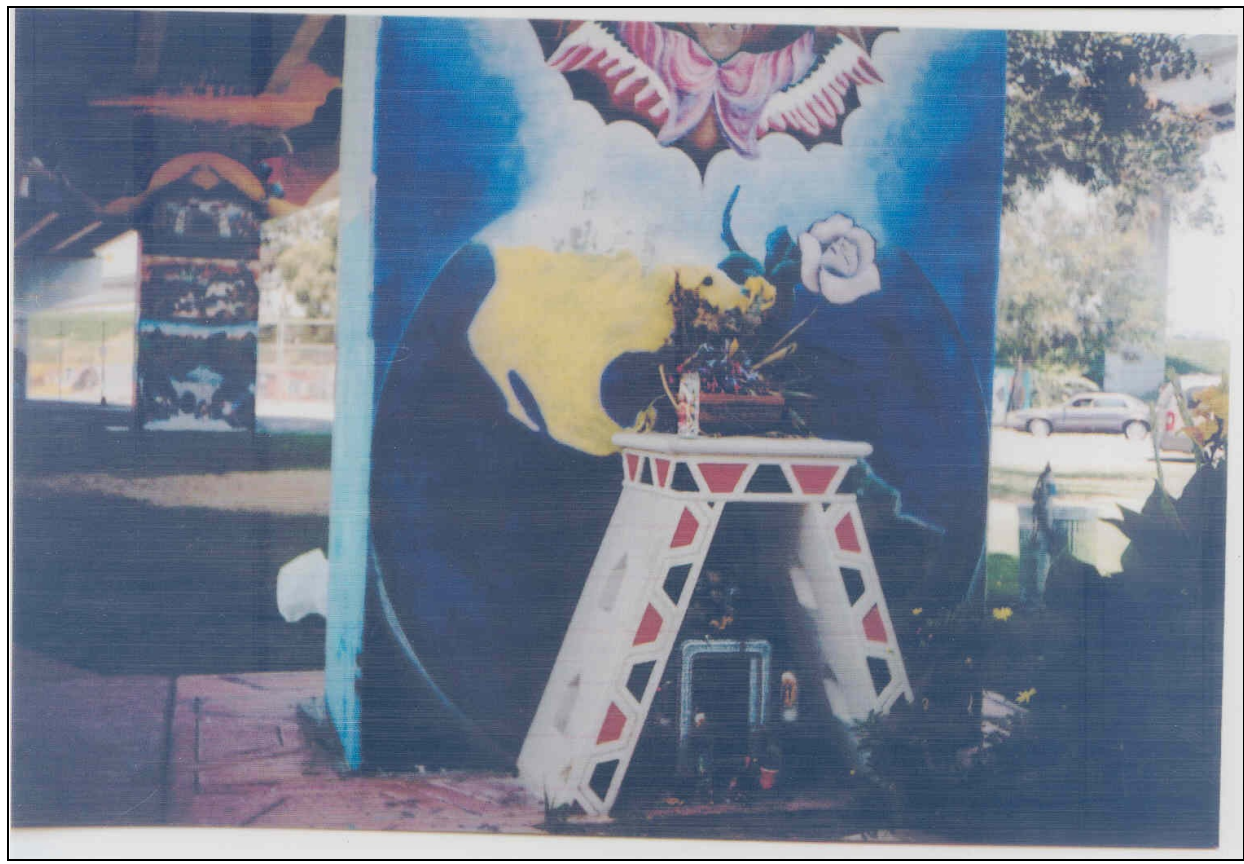

( 7 ) Fotografía de la autora 


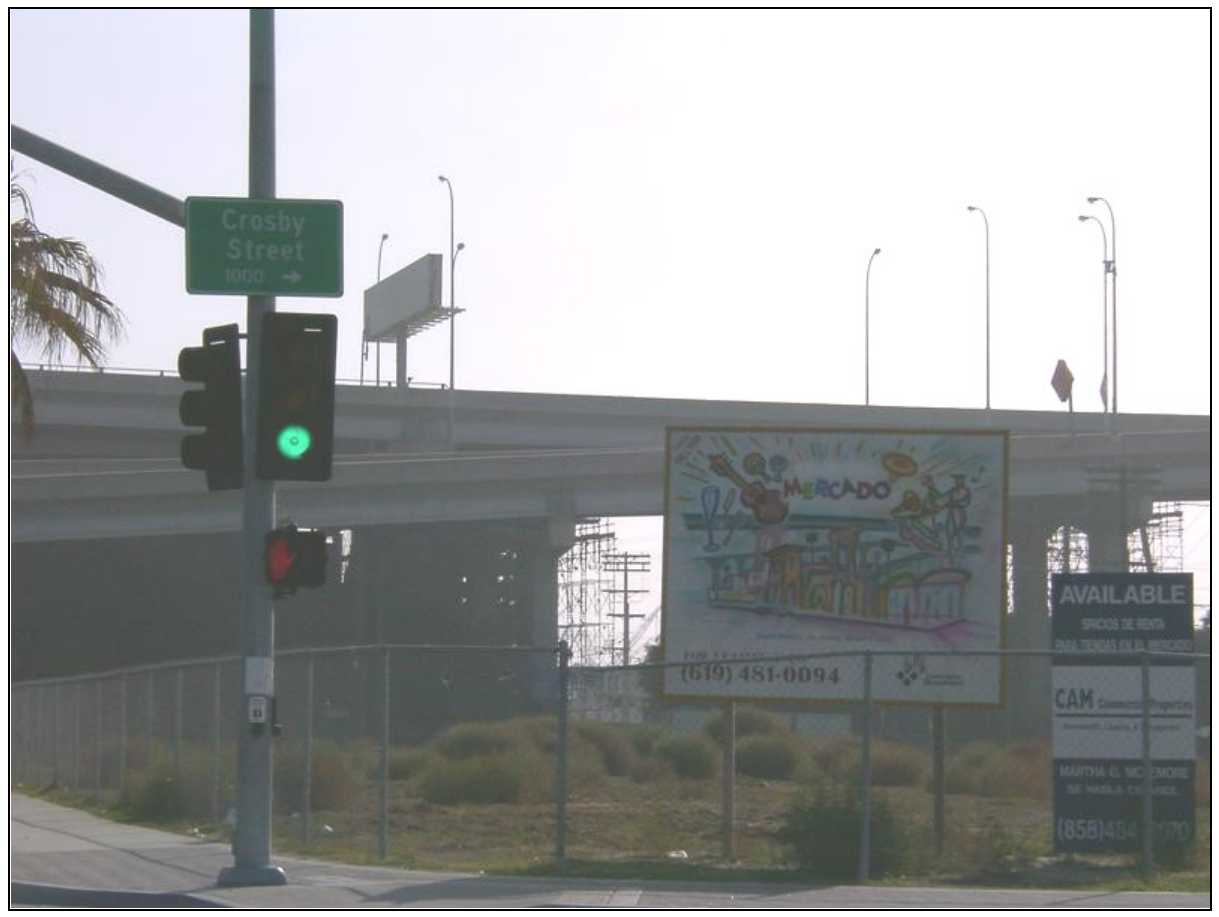

( 8 ) http://history.sandiego.edu/gen/projects/178/barriologan-pics.html

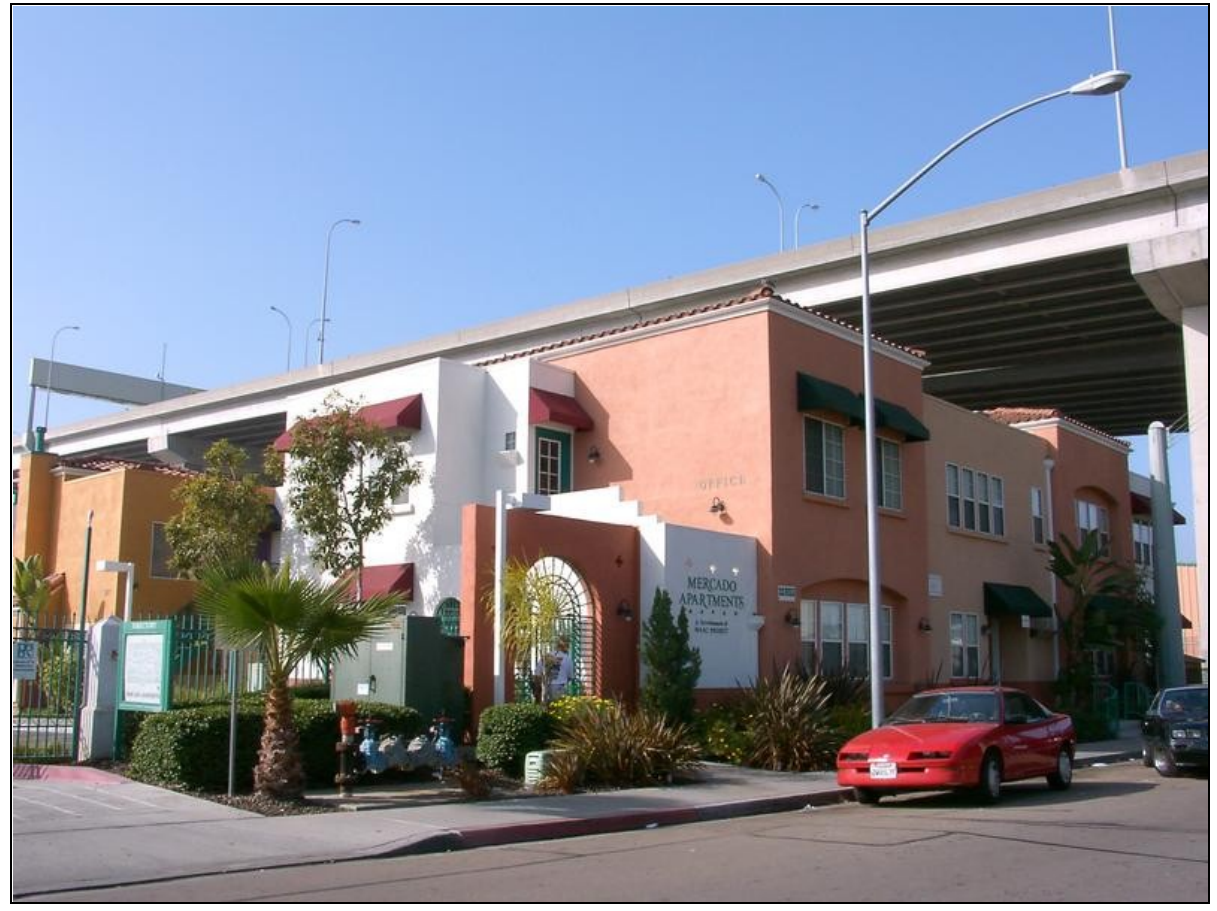


( 9 ) http://history.sandiego.edu/gen/projects/178/barriologan-pics.html

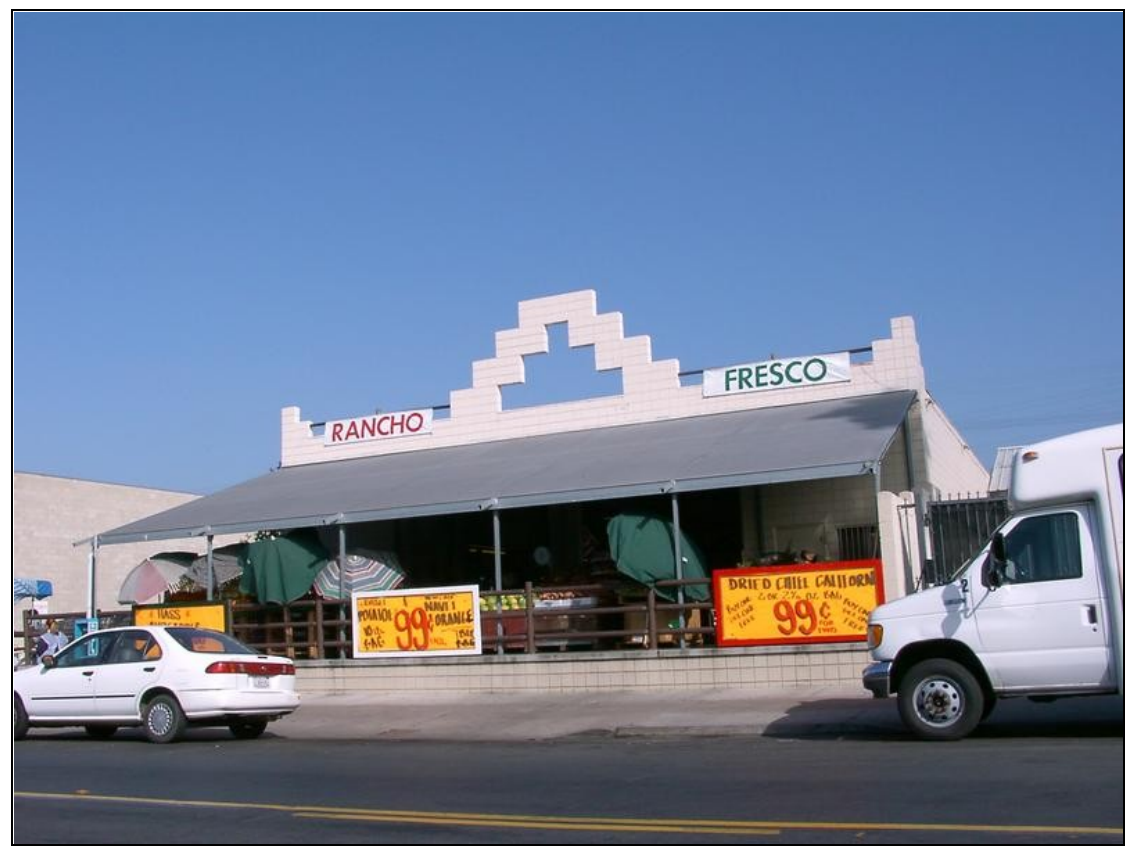

( 10 ) http://history.sandiego.edu/gen/projects/178/barriologan-pics.html 


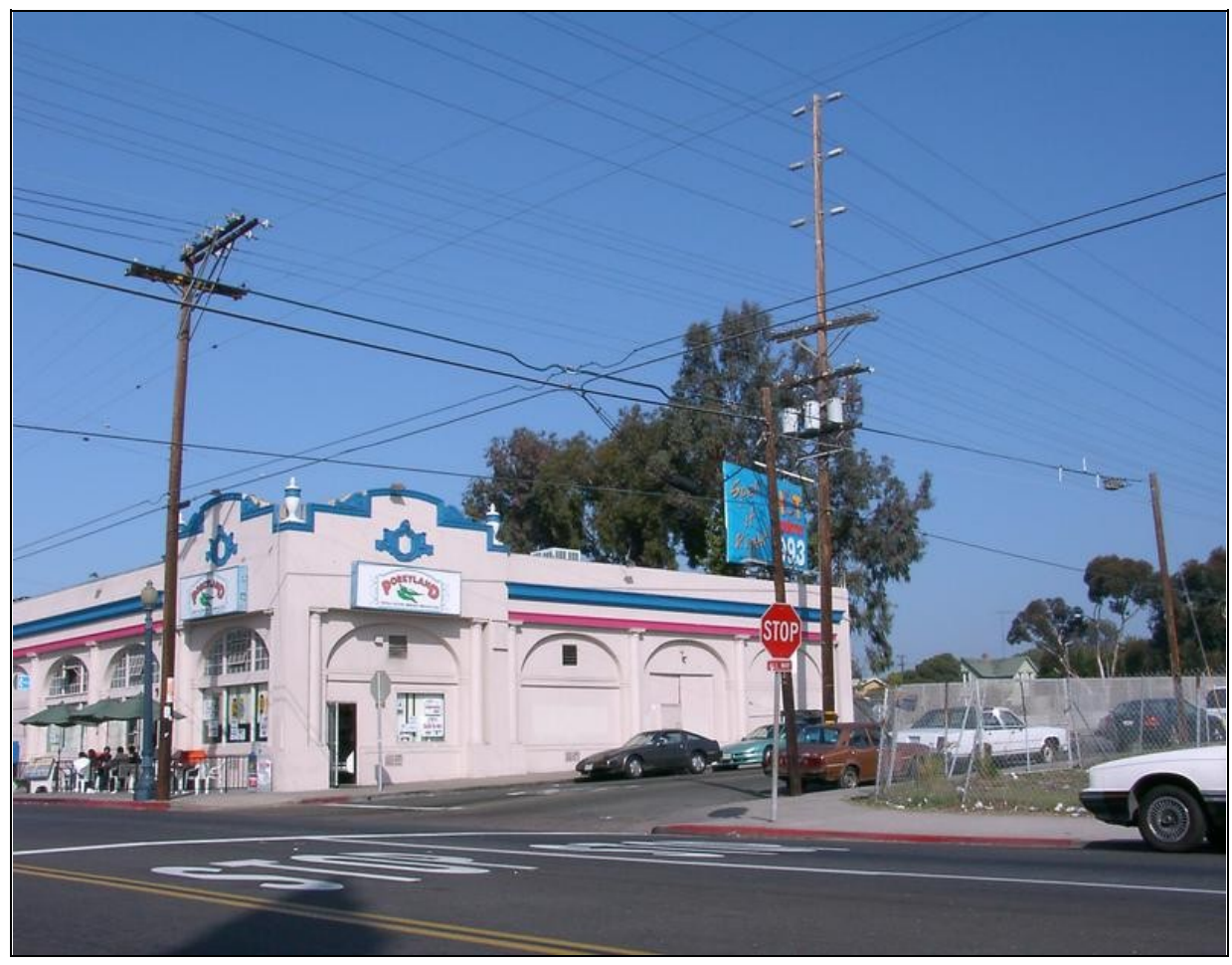

( 11 ) http://history.sandiego.edu/gen/projects/178/barriologan-pics.html

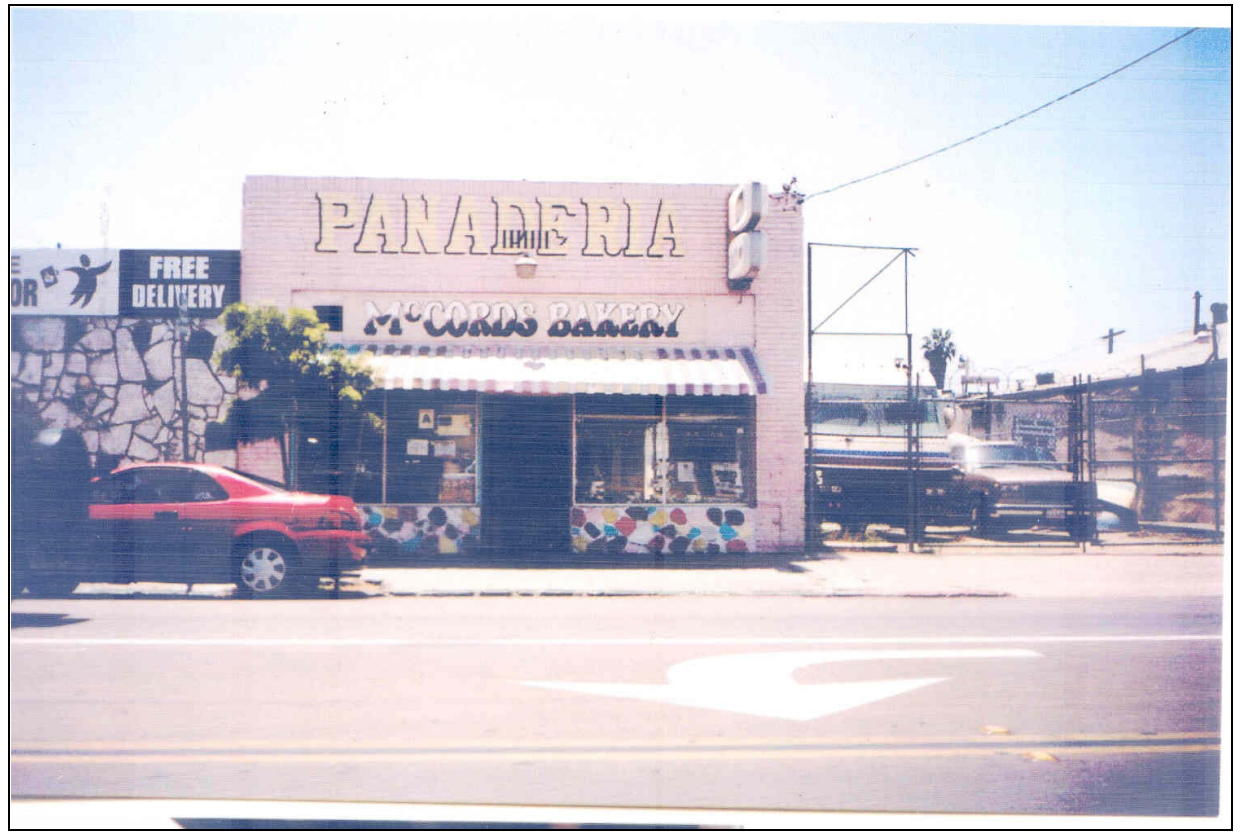

(12 ) Fotografía de la autora 


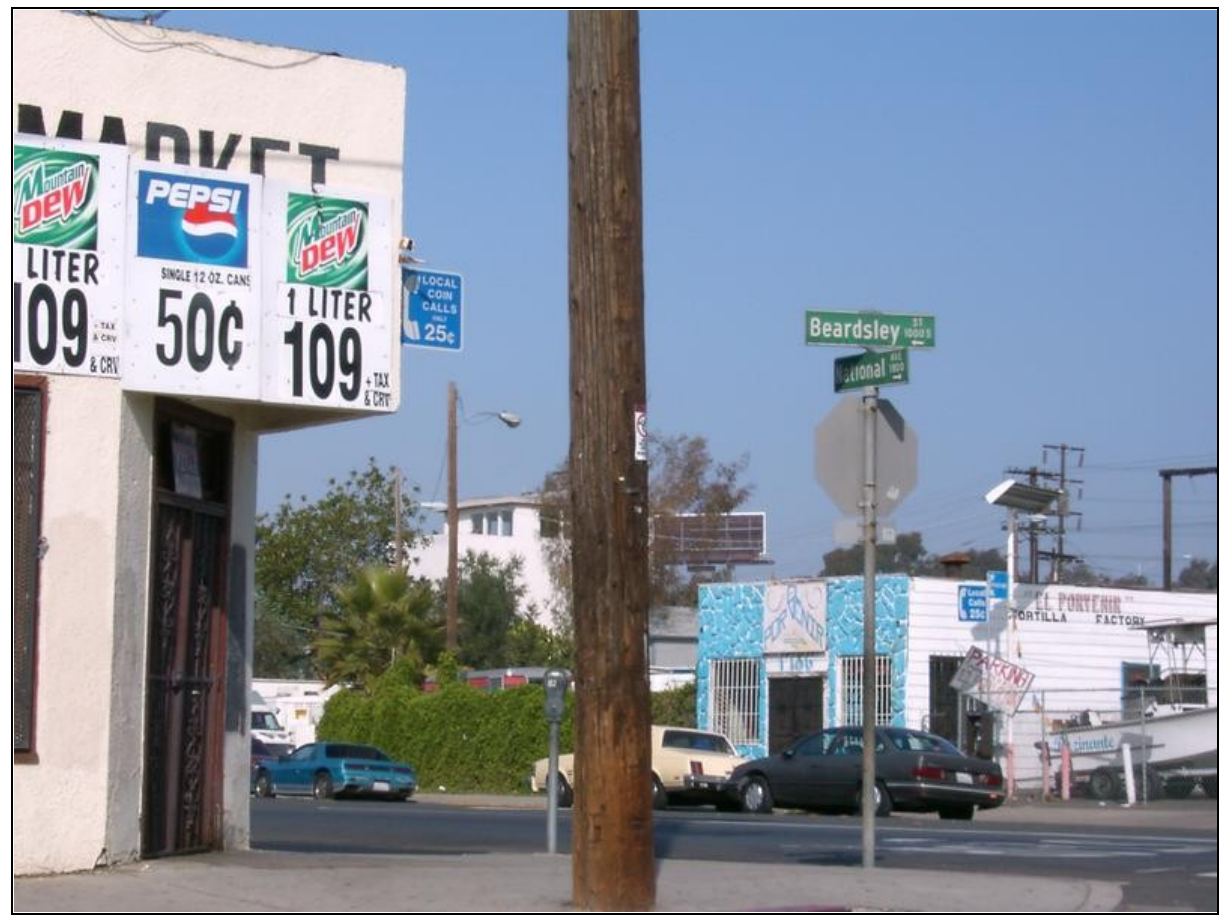

( 13 ) http://history.sandiego.edu/gen/projects/178/barriologan-pics.html

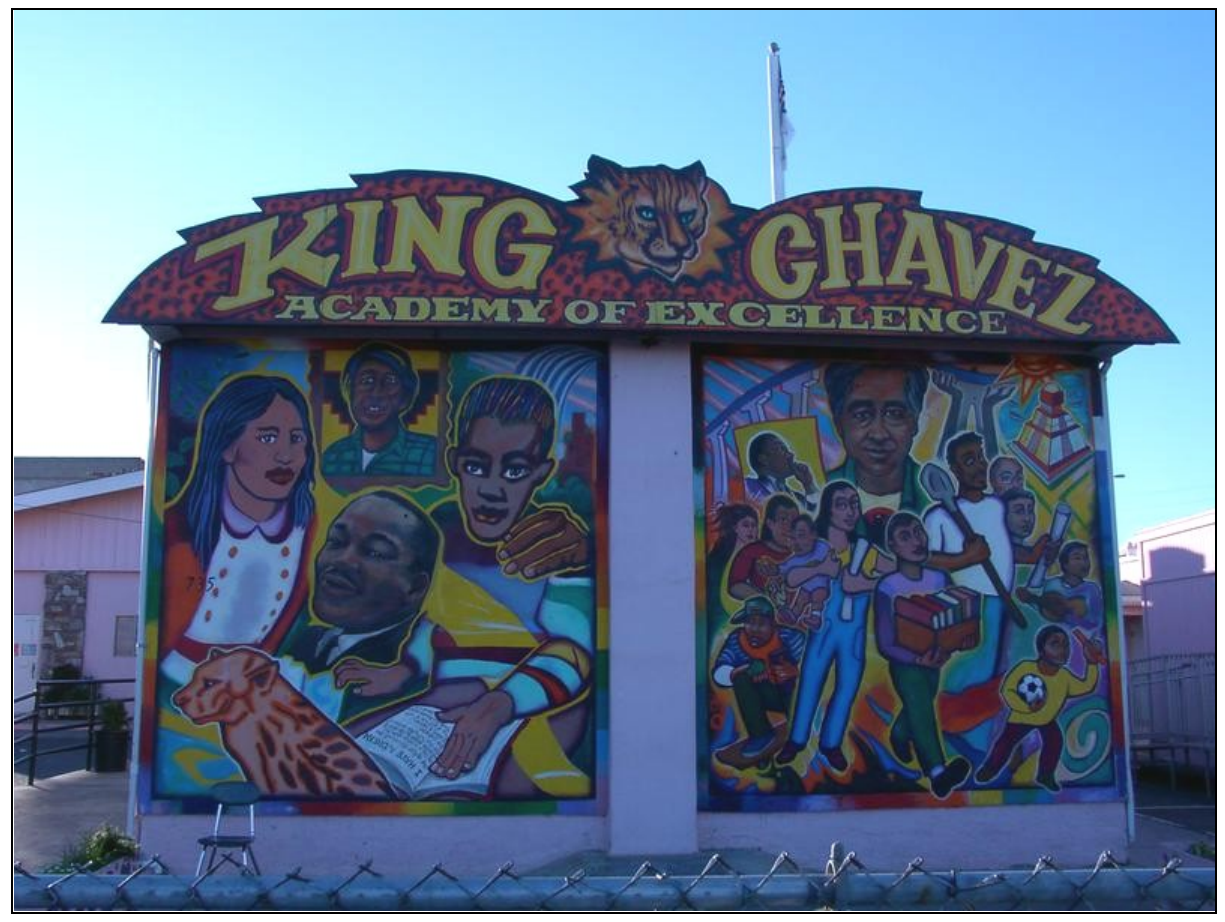

( 14 ) http://www.laprensa-sandiego.org/archieve/may31-02/020531.html 


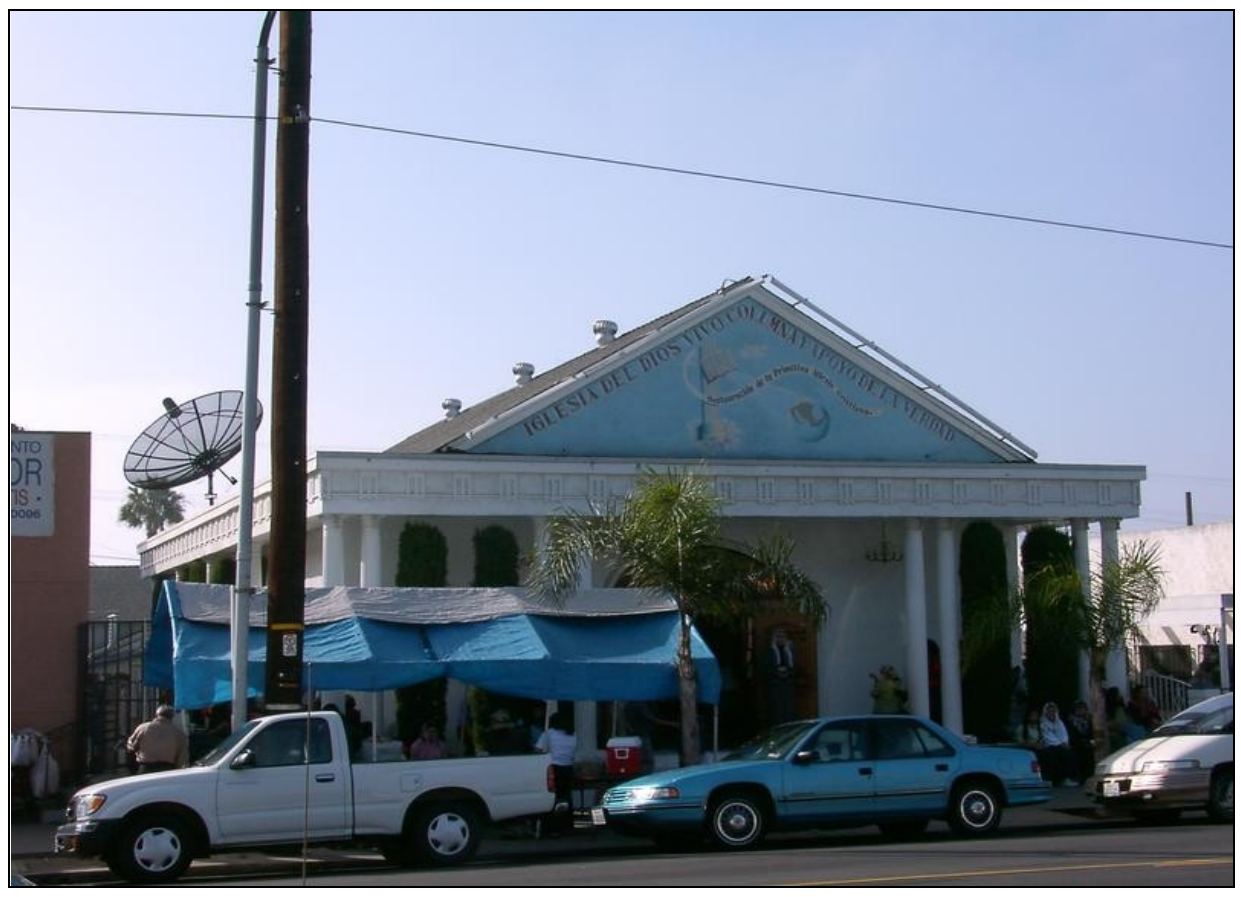

( 15 ) http://history.sandiego.edu/gen/projects/178/barriologan-pics.html 


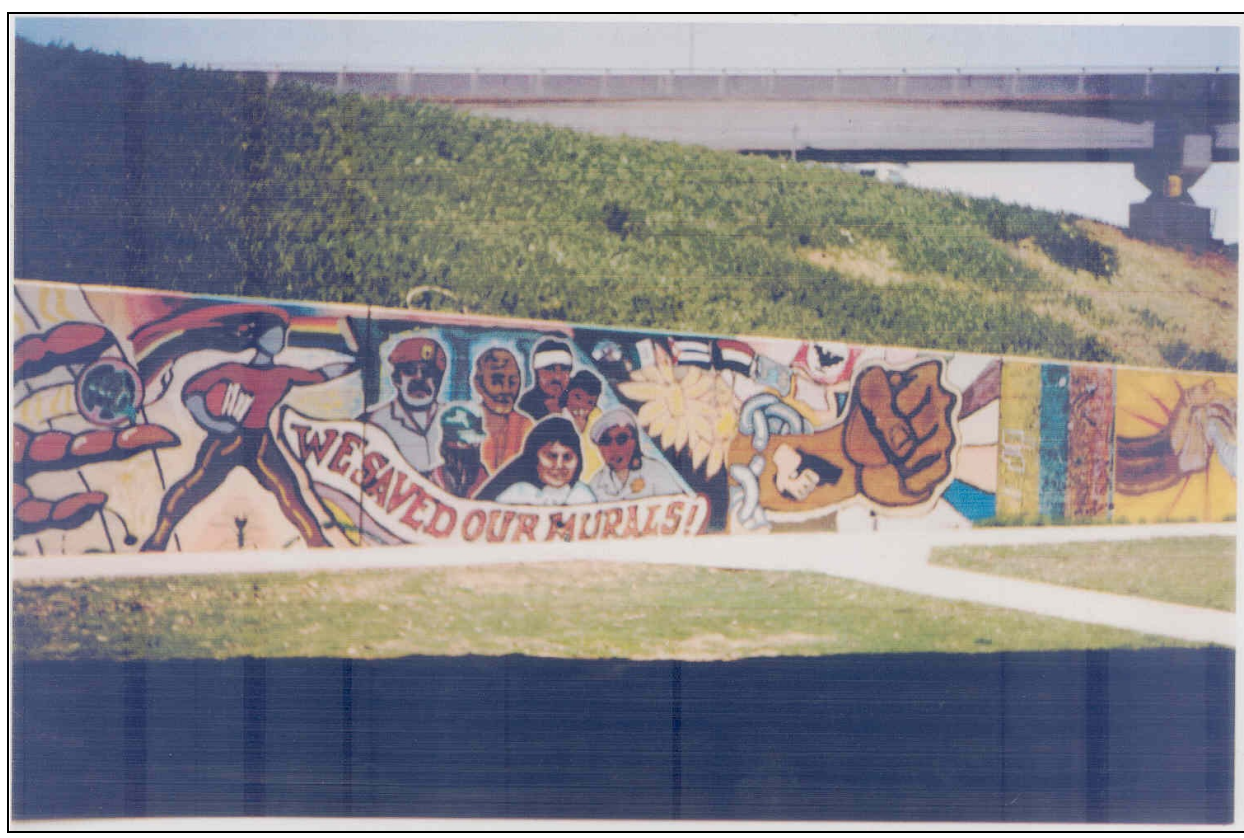

( 16 ) Fotografía de la autora 